\section{Report on the artifact}

The Council on Library and Information Resources (CLIR) has published The Evidence in Hand: Report of the Task Force on the Artifact in Library Collections. It reports the conclusions and recommendations of the task force of scholars, academic officers, librarians, and archivists convened in 1999 to consider the academic value of original materials.

Task force members examined the tension between providing access and preserving the original, the ways in which deterioration patterns of various media threaten research value, and how repositories can minimize unacceptable loss. They were asked to develop a framework to assist institutions with creating and evaluating appropriate retention policies. The report highlights preventive maintenance and use of surrogates as two key strategies for the protection of originals.

The report is available as a free pdf at http://www.clir.org/pubs/reports/pub103/ pub103.pdf. Printed copies cost $\$ 20$ and may be ordered online at the same URL. For more information, contact CLIR, 1755 Massachusetts Ave., N.W., Suite 500, Washington, D.C. 20036; phone: (202) 939-4750; fax: (202) 939-4765; e-mail: info@clir.org.

\section{Nationwide survey project}

The Council on Library and Information Resources (CLIR), the Association of Research Libraries (ARL), the University Libraries Group (ULG), and the Regional Alliance for Preservation (RAP) have received funding from the Institute for Museum and Library Services (IMLS) to support a survey of preservation activities in American colleges and universities. This twopart project will first, compile quantitative data about preservation and digitization using the ARL preservation statistics survey and other questionnaires, and second, develop qualitative data by visiting 20 representative institutions. The survey is intended to document the current state of preservation in American academic libraries and provide direction for future planning. It complements the Heritage Health Index project, which is surveying the condition of collections in cultural institutions of all types. Anne Kenney, of CLIR and Cornell University, is the project director.

For more information, contact Mary Case, ARL, 21 Dupont Circle, Suite 800, Washington, D.C. 20036; phone: (202) 296-2296; fax: (202) 872-0884; e-mail: marycase@arl.org; URL: http://www.arl.org.

\section{CCAHA photo workshops}

The Conservation Center for Art and Historic Artifacts (CCAHA) and the Intermuseum Conservation Association (ICA) will offer a threepart workshop series about photographic materials, "From Negative To Positive," in April 2002 at the Rock and Roll Hall of Fame and Museum in Cleveland, Ohio. On April 15, Debbie Hess Norris will teach "Identification and Care of Photographic Prints," on April 16, Andrew Robb will teach "Identification and Care of Photographic Negatives," and on April 17, Steve Puglia, Albert Albano, and Timothy Vitale will teach "Planning Your Digital Imaging Project." These workshops involve handson examination of photographic materials, so registration is limited.

Attendance at one workshop costs $\$ 60$, two workshops are $\$ 120$, and all three $\$ 170$. Discounts for CCAHA and ICA members or tuition assistance are available to help reduce the cost. For more information, contact Preservation Services, CCAHA, 264 South 23rd Street, Philadelphia, PA 19103; phone: (215) 545-0613; fax: (215) 735-9313; e-mail: ccaha@ccaha.org; URL: http://www ccaha.org.

\section{Photo electronic list}

In October 2001, Luis Nadeau started an electronic list devoted to photo conservation. Online discussion about conservation and restoration of photographic materials-including technical provenance, authentication, dating, identification, history of reproduction technologies or products, and the chemical and physical treatments of artifacts-is welcomed.

(continued on page 53)

Jane Hedberg is preservation program officer at Harvard University Library, e-mail: jane hedberg@harvard.edu; fax: (617) 496-8344 
Innovative Style and Technology) at the University of Iowa.

Connie Roberts is now director of Technical Services at Hamilton College in Clinton, New York.

Doralyn H. Rossmann has been appointed library systems analyst at Montana State University.

Cecilia D. Stafford is now associate dean of libraries at Tulane University.

Phoebe Terry is now government information librarian at the University of Southern Mississippi in Hattiesburg.

Carol Thompson has been appointed reference librarian at the College of DuPage in Glen Ellyn.

Mary Throumoulos has joined Rollins College as acquisitions librarian.

Virginia Toliver has been promoted to associate dean for administration at Washington University's Libraries and Information Technology.

Julie Voelck has been named associate dean and associate professor at the Kresge Library at Oakland University in Rochester, Michigan.

Ruth Vondracek has been named head of reference and instruction in the Valley Library at Oregon State University in Corvallis.

Penny A. Welbourne is the new catalog librarian II on the Rare Book Team at Yale University.

\section{Retirements}

Willis M. (Bill) Hubbard will retire in June 2002 as library director of Warren Wilson College in Asheville, North Carolina. A life member of ALA since 1968, Hubbard served two terms on the ACRL Board, chaired the College Library Section, served on the CERL News

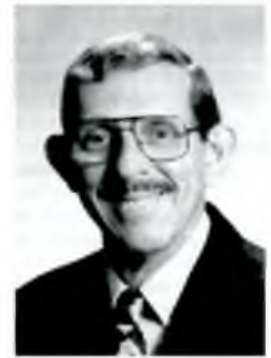

Bill (Willis M.) Hubbard
Editorial Board, and has been a member of many ACRL and ALA committees. He has served as a consultant to nearly 30 colleges and universities and has given programs at ACRL, ALA, CAUSE, Educom, the Coalition for Networked information, and other organizations.
Prior to his position at Warren Wilson College, Hubbard was library director at three other private colleges - most recently Gettysburg College (1983-96).

\section{Deaths}

Dan Foley, 58, nonbook cataloger/metadata librarian at the University of Wisconsin at Milwaukee's (UWM) Golda Meir Library, died November 17 while teaching a class for UWM's School of Information Studies. From 1982 to 1983, Foley worked as an intern in the UWM Library's cataloging department. Foley then accepted a professional position at Tulane University's HowardTilton Memorial Library, later taking jobs with Mobil Exploration and

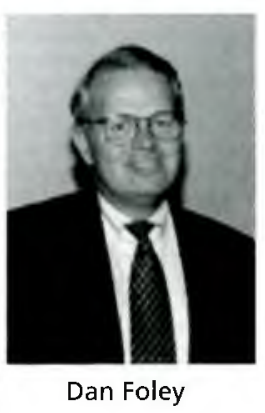
Producing, the library at the Xavier University of Louisiana, the Sims Memorial Library at Southeastern Louisiana University, and the Energy and Environmental Information Resources Center at the University of Louisiana at Lafayette. Foley began working as a professional at the UWM Libraries in September 2000.

James Edmund Maynard, associate professor in library science at The Citadel and a librarian there for 33 years, has died.

George D. Terry, vice provost and dean of libraries at the University of South Carolina (1991-2001), died October 20, 2001. Before assuming the position of dean, Terry served as director of the university's McKissick Museum and administrator for special projects, including development of an online library system to link the university's nine campuses. Terry excelled in facilitating the acquisition of notable materials for the libraries' special collection department.

("Preservation News" continued from page 43)

For more information, see http://groups. yahoo.com/group/photoconservation. To subscribe, send a blank message to photoconservationsubscribe@yahoogroups. com. 